\title{
Mastermind-Like Protein 3
}

National Cancer Institute

\section{Source}

National Cancer Institute. Mastermind-Like Protein 3. NCI Thesaurus. Code C117096.

Mastermind-like protein 3 (1134 aa, $\sim 122 \mathrm{kDa}$ ) is encoded by the human MAML3 gene.

This protein plays a role in both the positive regulation of transcription and signal transduction. 